\title{
Hubungan Pengetahuan dan Sikap dengan Motivasi Pemberian ASI Eksklusif oleh Ibu Muda (Usia <20 Tahun)
}

\section{The Relationship of Knowledge and Attitude to The Motivation of Exclusive Breastfeeding by Young Mother (Age <20 years)}

\author{
Desy Ratna Endriyeni ${ }^{1}$, Kusuma Estu Werdani ${ }^{2}$ \\ Program Studi Kesehatan Masyarakat,Universitas Muhammadiyah Surakartai ${ }^{1,2}$ \\ Email : kusuma.werdani@ums.ac.id
}

\begin{abstract}
Young mothers (aged $<20$ years) have limitations in the practice of exclusive breastfeeding for their babies. Lack of knowledge and experience of young mothers can form a lack of motivation in providing exclusive breastfeeding. This can have an impact on the declining coverage of exclusive breastfeeding in Boyolali if it is not immediately addressed. This study aimed to analyze the relationship between knowledge and attitude with the motivation of exclusive breastfeeding to young mothers in Boyolali Regency. This type of research is observational with cross-sectional approach. The population in this study were all young mothers (aged <20 years) recorded in 24 Puskesmas in Boyolali District as many as 370 people. While the sample that counted as many as 224 people with proportional random sampling technique. Data analysis using Chi square test. The results showed there was a relationship between maternal knowledge $(p=0,000)$ and the closeness of a weak relationship (phi $=0.330)$ and maternal attitudes $(p=0,000)$ with a strong enough relationship ( $\mathrm{phi}=0.517)$ with the motivation of exclusive breastfeeding to young mothers in the Boyolali. Future studies are needed to analyze the comparison of factors related to exclusive breastfeeding between the two groups (young mothers and adult mothers).
\end{abstract}

Keywords: Knowledge, Attitude, Motivation, Exclusive Breastfeeding

\begin{abstract}
ABSTRAK
Ibu muda (usia <20 tahun) memiliki keterbatasan dalam praktik pemberian ASI eksklusif kepada bayinya. Kurangnya pengetahuan dan pengalaman ibu muda bisa membentuk motivasi yang kurang baik dalam memberikan ASI eksklusif. Hal ini bisa berdampak pada semakin menurunnya cakupan ASI eksklusif di Kabupaten Boyolali apabila tidak segera ditangani. Penelitian ini bertujuan untuk menganalisis hubungan antara pengetahuan dan sikap dengan motivasi pemberian ASI eksklusif pada ibu muda di Kabupaten Boyolali. Jenis penelitian ini adalah observasional dengan pendekatan crosssectional. Populasi dalam penelitian ini adalah seluruh ibu muda (usia <20 tahun) yang tercatat di 24 Puskesmas di Kabupaten Boyolali sebanyak 370 orang. Sedangkan sampel yang terhitung sebanyak 224 orang dengan teknik proportional random sampling. Analisis data menggunakan uji Chi square. Hasil penelitian menunjukkan ada hubungan antara pengetahuan ibu $(\mathrm{p}=0,000)$ dengan keeratan hubungan lemah $(\mathrm{phi}=0,330)$ dan sikap ibu $(\mathrm{p}=0,000)$ dengan keeeratan hubungan cukup kuat $(\mathrm{phi}=0,517)$ dengan motivasi pemberian ASI eksklusif pada ibu muda di Kabupaten Boyolali. Penelitian selanjutnya diperukan untuk menganalisis perbandingan faktor-faktor yang berhubungan dengan ASI eksklusif antara dua kelompok (ibu muda dan ibu dewasa).
\end{abstract}

Keywords: ASI Eksklusif, Motivasi, Pengetahuan, Sikap. 


\section{PENDAHULUAN}

Pemberian Air Susu Ibu (ASI) eksklusif kepada bayi baru lahir merupakan salah satu indikator yang harus dicapai oleh pemerintah. Indikator ini penting untuk pencapaian status kesehatan ibu dan anak pada Rencana Pembangunan Jangka Menengah Nasional (RPJMN) 2015-2019. Peraturan Pemerintah Nomor 33 Tahun 2012 merupakan wujud dukungan pemerintah agar ASI diberikan kepada bayi sejak dilahirkan hingga usianya enam bulan tanpa tambahan makanan dan minuman lainnya.

ASI sangat bermanfaat bagi bayi dan ibunya. Akan tetapi, besarnya manfaat pemberian ASI eksklusif tidak diikuti oleh besarnya cakupan pemberian ASI. Berdasarkan data UNICEF (2013), cakupan ASI eksklusif di negara berkembang tergolong rendah, yaitu hanya $39 \%$. Indonesia merupakan salah satu negara berkembang yang pencapaian ASI eksklusifnya pada tahun 2017 masih jauh dari target nasional (80\%) yaitu hanya 35,73\% (Kemenkes RI, 2018). Sedangkan, Provinsi Jawa Tengah menempati urutan ke-13 pada tahun 2017 dengan persentase 41,89\%. Pencapaian ini belum mencapai target yang ditetapkan oleh Dinas Kesehatan Provinsi Jawa Tengah pada Rencana Strategis 2013-2018 yaitu sebesar 53\%. Salah satu kabupaten di Jawa Tengah yang sudah melebihi rata-rata persentase pemberian ASI eksklusif namun tidak masuk peringkat 10 besar yaitu Kabupaten Boyolali. Pada tahun 2017, Kabupaten Boyolali menempati urutan ke-15 dari 34 kabupaten di Jawa Tengah dengan persentase 58,3\% dan tahun 2016 sebesar 57,87\%. Meskipun persentase ini mengalami peningkatan, namun masih belum mencapai target pencapaian ASI eksklusif secara nasional (Dinas Kesehatan Provinsi Jawa Tengah, 2017).

Pemberian ASI eksklusif dipengaruhi oleh usia, pendidikan, dan motivasi dari ibu yang menyusui. Menurut Prabhasari (2011), usia merupakan ciri kedewasaan fisik maupun kematangan kepribadian yang erat hubungannya dengan pengambilan keputusan. Keputusan yang diambil akan lebih matang dan kuat apabila usia ibu sudah dewasa sehingga motivasi yang terbentuk juga lebih besar untuk memberikan ASI eksklusif kepada bayinya. Peningkatan pemberian ASI eksklusif dapat dilakukan dengan adanya peningkatan motivasi. Motivasi, baik yang berasal dari dalam (intrinsik) maupun dari luar (ekstrinsik), inilah yang akan menjadi faktor pendorong ibu untuk menyusui bayinya (Armini, 2015). Menurut Kartikasari dan Afifah (2009), motivasi ibu dalam memberikan ASI eksklusif dipengaruhi oleh faktor pendidikan, pengetahuan, dan peran tenaga kesehatan. Sebagian besar Ibu yang memiliki motivasi tinggi akan memberikan ASI secara eksklusif kepada bayinya karena ibu sadar manfaat ASI yang baik bagi ibu maupun bayinya.

Pengetahuan menjadi salah satu faktor yang dapat membentuk motivasi ibu untuk memberikan ASI eksklusif (Listyaningrum dan Vidayanti, 2016). Semakin tinggi tingkat pengetahuan ibu tentang ASI, maka semakin tinggi motivasi ibu dalam pemberian ASI eksklusif. Sekain itu, pengetahuan ibu yang tinggi juga akan menambah rasa percaya diri dan motivasi ibu untuk memberikan ASI secara eksklusif (Kartikasari dan Afifah, 2009). Sikap juga mempengaruhi motivasi ibu dalam pemberian ASI eksklusif. Ibu yang bersikap positif (mendukung) terhadap pemberian ASI eksklusif memiliki kecenderungan lebih besar dalam melakukan praktek pemberian ASI eksklusif (Chairil, 2014). Ibu yang bersikap positif mempunyai peluang 8,77 kali untuk memberikan ASI eksklusif dibandingkan yang mempunyai sikap negatif terhadap pemberian ASI eksklusif.

Peningkatan pemberian ASI eksklusif perlu dilakukan oleh semua ibu termasuk ibu muda ( $<20$ tahun). Pemberian ASI eksklusif ini akan membutuhkan perhatian lebih pada kelompok ibu muda yang memiliki risiko tinggi untuk tidak memberikan ASI kepada bayinya. Tingginya data pernikahan dini di Indonesie mengindikasikan bahwa tinggi pula kelompok ibu muda. Data Riskesdas tahunn 2013 menunjukkan bahwa perempuan muda di Indonesia dengan usia kurang dari 15 tahun sudah menikah sebesar 2,6\% dan sebesar 
23,9\% menikah pada usia 15-19 tahun. Menurut BPS (2016), Boyolali termasuk kabupaten dengan angka pernikahan dini yang tertinggi, terdapat dua kecamatan dengan persentase pernikahan dini tinggi yaitu Selo (40\%) dan Cepogo (38\%) pada tahun 2015.

Berdasarkan survei pendahuluan yang telah dilakukan terhadap delapan ibu muda (usia <20 tahun) yang menyusui di wilayah kerja Puskesmas Teras Kabupaten Boyolali, terdapat $62,5 \% \mathrm{ibu}$ memiliki motivasi intrinsik yang rendah untuk memberikan ASI. Mereka lebih memilih memberikan susu formula ketika berpergian. Sebesar $75 \%$ ibu muda memiliki pengetahuan yang kurang, terutama tentang manfaat pemberian ASI eksklusif kepada bayinya. Ibu muda juga bersikap negatif dalam memberikan ASI eksklusif. Hal ini ditunjukkan sebesar 87,5\% ibu muda lebih memilih memberikan makanan atau minuman tambahan kepada bayi pada saat terjadi masalah terhadap produksi ASI-nya. Penelitian tentang motivasi pemberian ASI eksklusif di Kabupaten Boyolali belum pernah dilakukan. Penelitian sebelumnya di Kabupaten Boyolali dilakukan oleh Cristiana (2016) terhadap ibu muda menyusui $\leq 20$ tahun tentang pengetahuan, status pekerjaan, dukungan keluarga dengan pemberian ASI eksklusif di wilayah kerja Banyudono 1 dan Banyudono 2. Oleh karena itu, peneliti tertarik untuk melakukan penelitian tentang hubungan pengetahuan dan sikap dengan motivasi pemberian ASI eksklusif pada ibu muda di Kabupaten Boyolali.

\section{METODE}

Jenis penelitian yang digunakan adalah penelitian kuantitatif analitik dengan menggunakan pendekatan cross-sectional. Penelitian ini dilaksanakan pada tanggal 21 Maret sampai 5 April 2019. Tempat penelitian ini meliputi 24 dari 26 Puskesmas di Kabupaten Boyolali. Puskesmas yang tidak diteliti yaitu Puskesmas Boyolali 1 dan Puskesmas Kemusu 1 dikarenakan ketersediaan data yang kurang lengkap.

Populasi dalam penelitian ini adalah seluruh ibu muda berusia $<20$ tahun yang tercatat di 24 Puskesmas Kabupaten Boyolali pada tahun 2018 sampai dengan bulan Agustus 2018 yang berjumlah jumlah 370 orang. Jumlah sampel minimal menggunakan rumus diperoleh nilai sebesar 208 sampel. Akan tetapi, dalam penelitian ini jumlah responden yang dilibatkan sebanyak 224 yang diambil dengan menggunakan teknik proportional random sampling. Responden akan di-eksklusikan apabila tiga kali didatangi tidak dapat ditemui untuk pengambilan data.

Cara pengumpulan data dilakukan dengan membagikan kuesioner untuk dijawab oleh responden secara langsung. Intrumen yang digunakan sudah diuji validitas dan reliabilitas sebelum dibagikan kepada responden. Analisis data digunakan untuk mengetahui hubungan antara variabel bebas (pengetahuan dan sikap) dengan variabel terikat (motivasi pemberian ASI eksklusif) menggunakan uji statistik Chi-square dengan tingkat signifikansinya $\mathrm{p}>0,05$.

\section{HASIL DAN PEMBAHASAN}

Penelitian ini dilakukan di 24 wilayah puskesmas se-Kabupaten Boyolali. Responden yang dilibatkan adalah ibu muda (usia <20 tahun) yang memiliki bayi usia 6-12 bulan sebanyak 224 orang. Gambaran karakteristik responden dapat dilihat pada Tabel 1. 
Tabel 1. Distribusi Frekuensi Karakteristik Responden pada Ibu Muda di Kabupaten Boyolali

\begin{tabular}{|c|c|c|}
\hline Karakteristik & Jumlah (n) & Persentase (\%) \\
\hline \multicolumn{3}{|l|}{ Umur Responden } \\
\hline 13 Tahun & 1 & 0,4 \\
\hline 15 Tahun & 1 & 0,4 \\
\hline 16 tahun & 2 & 0,9 \\
\hline 17 Tahun & 19 & 8,5 \\
\hline 18 Tahun & 40 & 17,9 \\
\hline 19 Tahun & 161 & 71,9 \\
\hline \multicolumn{3}{|c|}{ Mean : 18,58 ; Min : 13 ; Max : 19} \\
\hline \multicolumn{3}{|l|}{ Tingkat Pendidikan } \\
\hline Tidak Tamat SD & 5 & 2,2 \\
\hline Tamat SD & 34 & 15,2 \\
\hline Tamat SMP & 106 & 47,3 \\
\hline Tamat SMA & 79 & 35,3 \\
\hline \multicolumn{3}{|l|}{ Jenis Pekerjaan } \\
\hline Tidak Bekerja & 203 & 90,6 \\
\hline Pegawai Swasta & 1 & 0,4 \\
\hline Wiraswasta & 6 & 2,8 \\
\hline Buruh & 11 & 4,9 \\
\hline Lainnya & 3 & 1,3 \\
\hline \multicolumn{3}{|l|}{ Pendapatan Responden } \\
\hline Tidak Berpenghasilan & 203 & 90,6 \\
\hline Kurang UMR $(<1.650 .000)$ & 17 & 7,6 \\
\hline UMR (>1.650.000) & 4 & 1,8 \\
\hline \multicolumn{3}{|c|}{ Tempat Pelayanan yang Dikunjungi } \\
\hline Bidan & 172 & 76,8 \\
\hline Puskesmas & 34 & 15,2 \\
\hline Klinik Swasta & 7 & 3,1 \\
\hline Rumah Sakit & 11 & 4,9 \\
\hline
\end{tabular}

Usia responden terbanyak adalah 19 tahun sebanyak 161 orang $(71,9 \%)$, sedangkan yang paling sedikit yaitu usia 13 tahun $(0,4 \%)$ sebagai kategori usia termuda. Sebagian besar responden menyelesaikan pendidikan setingkat SMP (106 orang atau 47,6\%), sedangkan tingkat pendidikan terendah reponden yaitu belum tamat SD sebanyak 5 orang $(2,2 \%)$. Mayoritas responden tidak bekerja (Ibu Rumah Tangga/ IRT) yaitu sebanyak 203 (90,6\%). Ada sebanyak 21 responden berstatus bekerja dan mayoritas berpendapatan kurang dari UMR (80,9\%). Sebagian besar responden memilih untuk mengunjungi bidan jika membutuhkan pelayanan kesehatan $(76,8 \%)$ (Tabel 1).

Tabel 2. Gambaran Status Pengetahuan, Sikap, Motivasi Pemberian ASI eksklusif pada Ibu Muda di Kabupaten Boyolali

\begin{tabular}{lcc}
\hline \multicolumn{1}{c}{ Variabel } & Jumlah (n) & Persentase (\%) \\
\hline Pengetahuan & & \\
Rendah & 88 & 39,3 \\
Tinggi & 136 & 60,7 \\
\hline Sikap & & \\
Negatif & 115 & 51,3 \\
Positif & 109 & 48,7 \\
\hline Motivasi Pemberian ASI Eksklusif & & \\
Rendah & 117 & 52,2 \\
Tinggi & 107 & 47,8 \\
\hline
\end{tabular}

Ibu muda yang berpengetahuan tinggi $(60,7 \%)$ tentang ASI eksklusif memiliki persentase jauh lebih tinggi dengan yang berpengetahuan rendah $(39,2 \%)$. Hal ini 
berkebalikan dengan ibu muda yang bersikap negatif yang memiliki persentase lebih tinggi dibandingkan dengan yang bersikap positif, meskipun dengan selisih yang tidak terlalu besar. Sedangkan ibu muda yang memiliki motibasi rendah juga lebih banyak daripada yang memiliki motivasi tinggi.

Tabel 3. Hubungan Pengetahuan dan Sikap dengan Motivasi Pemberian ASI eksklusif pada Ibu Muda di Kabupaten Boyolali

\begin{tabular}{|c|c|c|c|c|c|c|c|c|}
\hline \multirow{3}{*}{ Variabel } & \multicolumn{4}{|c|}{ Motivasi Pemberian ASI Eksklusif } & \multicolumn{2}{|c|}{ Total } & \multirow{3}{*}{$p$ value } & \multirow{3}{*}{$\begin{array}{c}\text { Koefisien } \\
\text { phi }\end{array}$} \\
\hline & \multicolumn{2}{|c|}{ Rendah } & \multicolumn{2}{|c|}{ Tinggi } & \multirow[b]{2}{*}{ n } & \multirow{2}{*}{$\%)$} & & \\
\hline & $\mathbf{N}$ & $(\%)$ & $\mathbf{n}$ & $(\%)$ & & & & \\
\hline \multicolumn{9}{|c|}{ Pengetahuan } \\
\hline Rendah & 64 & 72,7 & 24 & 27,3 & 88 & 100 & $<0,0001$ & 0,330 \\
\hline Tinggi & 53 & 39 & 83 & 61 & 136 & 100 & & \\
\hline \multicolumn{9}{|l|}{ Sikap } \\
\hline Negatif & 89 & 77,4 & 26 & 22,6 & 115 & 100 & $<0,0001$ & 0,517 \\
\hline Positif & 28 & 25,7 & 81 & 74,3 & 109 & 100 & & \\
\hline
\end{tabular}

Hasil uji statistik pada Tabel 3 menunjukkan bahwa ada hubungan antara pengetahuan dengan motivasi pemberian ASI eksklusif pada ibu muda di Kabupaten Boyolali dengan keeratan hubungan yang lemah (koefisien phi=0,330). Selain itu juga ada hubungan antara sikap dengan motivasi pemberian ASI eksklusif pada ibu muda di Kabupaten Boyolali dengan keeratan hubungan yang cukup kuat (koefisien phi=0,517).

\section{Hubungan Pengetahuan dengan Motivasi Pemberian ASI Eksklusif pada Ibu Muda di Kabupaten Boyolali}

Hasil uji statistik dalam penelitian ini menunjukkan bahwa ibu muda dengan pengetahuan yang tinggi berpeluang memiliki motivasi tinggi dalam memberikan ASI eksklusif dibandingkan dengan ibu muda yang berpengetahuan rendah. Sejalan dengan Setiasih (2011), ibu yang memiliki pengetahuan baik tentang ASI eksklusif maka motivasi dalam memberikan ASI eksklusif semakin tinggi. Menurut Rahmawati (2010), hal tersebut disebabkan oleh pengetahuan ibu muda tentang ASI berperan penting dalam pelaksanaan ASI eksklusif, semakin tinggi pengetahuan ibu maka semakin termotivasi untuk memberikan ASI eksklusif.

Berdasarkan hasil penelitian, sebanyak 154 responden $(68,75 \%)$ menganggap bahwa bayi 0-6 bulan boleh diberikan makanan/minuman lain ketika putting ibu lecet/tenggelam. Meskipun puting ibu lecet/tenggelam, bayi tetap masih bisa disusui dengan baik oleh ibunya selama kondisi fisiologisnya masih memungkinkan. Hal ini mengindikasikan bahwa ibu muda belum benar-benar memahami arti pemberian ASI secara eksklusif. Padahal, menurut Peraturan Pemerintah Nomor 33 Tahun 2012, ASI eksklusif adalah hanya memberikan ASI kepada bayi sejak dilahirkan selama enam bulan tanpa menambahkan dan/atau mengganti dengan makanan atau minuman lain.

Tingkat pengetahuan yang mempengaruhi motivasi pemberian ASI eksklusif antara lain pendidikan, informasi yang diperoleh, pengalaman, dan lingkungan. Sebagian besar ibu muda dalam penelitian ini memiliki pendidikan rendah. Meskipun demikian, ibu muda berpendidikan rendah tersebut yang memiliki pengetahuan tinggi lebih banyak dibandingkan dengan yang pengetahuan rendah tentang ASI eskklusif. Hal ini sangat memungkinkan dikarenakan semakin majunya tingkat teknologi, sehingga ibu muda dapat dengan mudah mengakses informasi tentang ASI eksklusif secara daring dari berbagai macam sumber dari smartphone yang mereka miliki. Oleh karena itu, pendidikan tidak sepenuhnya mempengaruhi tingkat pengetahuan ibu muda. Selain itu, mayoritas responden memperoleh informasi mengenai ASI dari bidan. Sebagaimana data penelitian 
menunjukkan bahwa tempat pelayanan yang sering dikunjungi oleh ibu muda selama kehamilan adalah bidan. Menurut Nasution (2016), pada masa kehamilan merupakan masa dimana ibu siap memutuskan memberikan ASI eksklusif kepada anak atau tidak. Hasil wawancara menunjukkan bahwa informasi yang diberikan oleh bidan kepada ibu muda selama pemeriksaan kehamilan meliputi manfaat kolostrum, cara mempersiapkan keluarnya ASI, dan manfaat pemberian ASI secara eksklusif bagi ibu dan bayinya. Hal ini pastinya akan mempengaruhi tingginya motivasi ibu dalam memberikan ASI secara eksklusif.

Pengetahuan ibu muda tentang ASI eksklusif yang sudah baik tidak akan berdampak baik dalam praktiknya apabila peran keluarga dan lingkungan sekitar kurang baik. Sebagian responden penelitian menyatakan bahwa keluarga mengizinkan ibu untuk memberikan susu formula kepada bayi $<6$ bulan. Ini menunjukkan bahwa ibu muda kurang mendapatkan dukungan yang baik dalam memberikan ASI eksklusif. Keluarga responden menganggap bahwa memberikan susu formula lebih praktis daripada menyusui. Petugas kesehatan masih diperlukan untuk melakukan upaya promotif kepada masyarakat agar tidak mengganti ASI dengan susu formula.

\section{Hubungan Sikap dengan Motivasi Pemberian ASI Eksklusif pada Ibu Muda di Kabupaten Boyolali}

Hasil uji statistik menunjukkan bahwa ibu muda dengan sikap positif berpeluang memiliki motivasi tinggi dalam memberikan ASI eksklusif dibandingkan dengan ibu muda yang memiliki sikap negatif. Hasil penelitian ini sejalan dengan penelitian Chairil (2014) yang dilakukan di Puskesmas Pembantu KM 18 Bencah Kalubi, Pekanbaru, yang menunjukkan bahwa ada hubungan sikap ibu dengan motivasi pemberian ASI eksklusif oleh ibu yang memiliki bayi usia 6-24 bulan ( $p$ value $=0,007$ ).

Terdapat berbagai faktor yang mempengaruhi sikap untuk mendorong (memotivasi) seseorang yang memberikan ASI eksklusif yaitu pengetahuan yang baik dan memiliki lebih banyak waktu di rumah sehingga mampu untuk lebih fokus memberikan ASI eksklusif pada bayinya. Berdasarkan hasil penelitian ini, sebagian besar ibu muda memiliki pengetahuan yang tinggi mengenai ASI. Pengetahuan yang baik mempengaruhi ibu dalam bersikap positif untuk memberikan ASI eksklusif. Hal ini dapat ditunjukkan oleh responden yang menyatakan setuju bahwa mengkonsumsi makanan bergizi dapat memperlancar produksi ASI. Oleh karena itu, ibu mengetahui cara untuk meningkatkan produksi ASI sehingga ibu setuju untuk mengkonsumsi makanan bergizi agar produksi ASI menjadi lancar.

Faktor lain yang menyebabkan sikap positif pada ibu muda yaitu ibu memiliki waktu luang yang banyak karena mayoritas sebagai ibu rumah tangga. Waktu inilah yang selayaknya akan menjadi motivasi kuat bagi ibu muda untuk memberikan ASI eksklusif. Waktu ini menjadi kendala bagi ibu muda yang status bekerja. Meskipun hasil penelitian Cristiana, dkk (2016) menunjukkan bahwa status pekerjaan tidak berhubungan dengan pemberian ASI eksklusif oleh ibu muda di wilayah Puskesmas Banyudini 1 dan Banyudini 2, Boyolali. Sebagian besar responden dalam penelitian ini juga setuju untuk memberikan susu formula apabila ibu sedang bekerja. Padahal, susu formula tidak mengandung antibodi yang dapat melindungi bayi maupun hormon pertumbuhan sehingga tidak dapat mencukupi kebutuhan bayi (Roesli, 2009). Oleh karena itu, pengetahuan ibu tentang manajemen laktasi sangat diperlukan, khususnya bagi ibu bekerja, agar lebih mempersiapkan diri dalam pemberian ASI eksklusif saat sudah mulai bekerja. 


\section{KESIMPULAN}

Sebagian ibu muda (usia <20 tahun) di Kabupaten Boyolali memiliki pengetahuan yang tinggi tentang ASI eksklusif, akan tetapi juga memiliki sikap yang negatif terhadap pemberian ASI eksklusif. Hal ini berdampak pada motivasi pemberian ASI yang rendah pada ibu muda tersebut lebih tinggi persentasenya dibandingkan dengan ibu muda yang memiliki motivasi tinggi. Hasil analisis menunjukkan hubungan yang signifikan antara pengetahuan dan sikap dengan pemberian ASI eksklusif pada ibu muda di Kabupaten Boyolali.

\section{SARAN}

Penelitian lebih lanjut bisa melakukan analisis perbandingan faktor-faktor yang lebih mendalam antara dua kelompok ibu, antara ibu muda dan ibu dewasa, dengan praktik pemberian ASI eksklusif.

\section{DAFTAR PUSTAKA}

Armini, N. W., Somoyani, N. K., \& Budiani, N. N. (2015). Perbedaan Motivasi Intrinsik dan Motivasi Ekstrinsik Dalam Pemberian Air Susu Ibu (ASI) Oleh Ibu Menyusui Eksklusif Dengan Ibu Menyusui Tidak Eksklusif. Jurnal Skala Husada, 12(1), 8-14.

Badan Pusat Statistik (BPS) Provinsi Jawa Tengah. (2016). Provinsi Jawa Tengah Dalam Angka 2016. Jawa Tengah: BPS Provinsi Jawa Tengah

Chairil, D. A. (2014). Hubungan Pengetahuan dengan Sikap Ibu Terhadap ASI Eksklusif di Wilayah Kerja Puskesmas Pembantu KM 18 Bencah Kelubi Kampar Kiri Tahun 2011. Jurnal Photon, 5(1), 33-38.

Cristiana, EN., Wijayanti, AC., Werdani, KE. (2016). Faktor-Faktor yang Berhubungan dengan Pemberian ASI Eksklusif pada Ibu Muda di Wilayah Kerja Puskesmas Banyono 1 dan Banyudono 2. [Naskah Publikasi]. Surakarta: Universitas Muhammadiyah Surakarta

Dinas Kesehatan Provinsi Jawa Tengah. (2014). Rencana Strategis Dinas Kesehatan Provinsi Jawa Tengah Tahun 2013-2015. Jawa Tengah: Dinas Kesehatan Provinsi Jawa Tengah

Dinas Kesehatan Provinsi Jawa Tengah. (2018). Profil Kesehatan Provinsi Jawa Tengah Tahun 2017. Jawa Tengah: Dinas Kesehatan Provinsi Jawa Tengah

Kartikasari, R. I., \& Afifah, D. N. (2009). Hubungan Antara Motivasi dengan Pemberian ASI Eksklusif di Desa Balun Kecamatan Turi Kabupaten Lamongan. SURYA, 1(2), 57-64.

Kemenkes RI. (2015). Laporan NasionalRiset Kesehatan Dasar (Riskesdas). Jakarta: Badan Penelitian dan Pengembangan Kesehatan Kemenkes RI

Kemenkes RI. (2018). Profil Kesehatan Indonesia Tahun 2017.Jakarta: Kementrian Kesehatan RI.

Listyaningrum, T. U., \& Vidayanti, V. (2016). Tingkat Pengetahuan dan Motivasi Ibu Berhubungan dengan Pemberian ASI Eksklusif pada Ibu Bekerja. JNKI, 4(2), 55-62.

Nasution, S. I., Liputo, N. I., \& Mahdawaty. (2016). Faktor-Faktor yang Berhubungan dengan Pola Pemberian ASI Eksklusif di Wilayah Kerja Puskesmas Bungus Tahun 2014. Jurnal Kesehatan Andalas, 5(3), 635-639. 
Peraturan Pemerintah Republik Indonesia Nomor 33 Tahun 2012 tentang Pemberian ASI Eksklusif.

Prabhasari, T. S. (2011). Faktor-Faktor yang Mempengaruhi Motivasi Ibu Hamil Menyusui secara Eksklusif di Puskesmas Kasihan I Bantul Yogyakarta. Mutiara Medika, 11(1), 46-54.

Rahmawati, M. D. (2010). Faktor-Faktor yang Mempengaruhi Pemberian ASI Eksklusif pada Ibu Menyusui di Kelurahan Pedalangan Kecamatan Banyumanik Kota Semarang. Jurnal KesMaDaSka, 1(1), 8-17.

Roesli, U. (2009). Mengenal ASI Eksklusif. Jakarta: PT Trubus Agriwidya.

Setiasih, A, Y. (2011).Hubungan Tingkat Pengetahuan dengan Motivasi Pemberian ASI Eksklusif pada Ibu Nifas di Rumah Bersalin Rachmi Yogyakarta. [Naskah Publikasi]. Yogyakarta: Sekolah Tinggi Ilmu Kesehatan 'Aisyiyah Yogyakarta'

UNICEF. (2013). Breastfeeding. http// www.unicef.org/nutrition/index 24824.html. Diakses pada 22 Oktober 2018 